\title{
New sighting of the endangered species blackchin guitarfish, Rhinobatos cemiculus, in the South Aegean Sea
}

\author{
Halit Filiz ${ }^{1}$, Gökçen Bilge ${ }^{1}$, Daniela Giannetto ${ }^{2}$ and Sercan Yapıcı ${ }^{1 *}$
}

\begin{abstract}
Background: A new record of the endangered species blackchin guitarfish, Rhinobatos cemiculus (925 mm TL) is here reported from South Aegean Sea. On 11 January 2015, a single specimen was collected by longline off from the Kuşadası Bay, Turkey. This new finding confirms the presence of the species along the Anatolian coasts of Aegean Sea and shows that the species is occuring in the South Aegean Sea.

Results: Rhinobatos cemiculus belonging to family Rhinobatidae was identified and its distribution was compared for the Aegean and Mediterranean Sea based on literature. The main identification and some measurements of morphometric characteristics were given.

Conclusions: In terms of distribution of fish taxa, Aegean coasts of Turkey has the highest diversity with 449 species, which of 64 species belong to Elasmobranchii. This report aims to close information gaps in distribution endangered cartilaginous fish throughout the Turkish Aegean coasts.
\end{abstract}

Keywords: Aegean Sea, Anatolian coast, Endangered species, Blackchin guitarfish

\section{Background}

The family Rhinobatidae consists of 52 species worldwide, two of which have been found to occur in the Mediterranean (Rhinobatos cemiculus Geoffroy SaintHilaire 1817 and Rhinobatos rhinobatos (Linnaeus 1758)). Rhinobatos cemiculus is widely distributed eastern Atlantic from Portugal to Angola (McEachran and Capapé, 1984), mostly on sandy and muddy bottoms to maximum depth of $100 \mathrm{~m}$ (Capapé and Zaouali, 1994). It is a prevalent Guitarfish in the Central Mediterranean Sea (i.e. Gulf of Gabés) (Echwikhi et al. 2013) and North eastern Atlantic (e.g. Senegalese coast) (Seck et al. 2004).

In the Mediterranean, it has been reported from France (Capapé et al. 2006) Italy (Tortonese, 1956), Morocco (Lloris and Rucabado, 1998), Tunisia (Mejri et al. 2004; Echwikhi et al. 2013), Turkey (Iskenderun Bay: Başusta et al. 2012), and Israel (Ben-Tuvia, 1953; Golani, 1996) whereas its occurrence is rarely documented along the Hellenic and Anatolian coasts of

\footnotetext{
* Correspondence: sercanyapici@mu.edu.tr

${ }^{1}$ Faculty of Fisheries, Muğla Sıtkı Koçman University, Kötekli, Muğla, Turkey Full list of author information is available at the end of the article
}

Aegean Sea, and to date only a few records from Rhodes Island (Corsini-Foka, 2009) and Izmir Bay (Akyol and Capapé, 2014) are known (Fig. 1).

Rhinobatos cemiculus is considered as a target species in small-scale fisheries but on the other hand it is known by-catch in several non-target fisheries, especially in bottom trawl fisheries (Enajjar et al. 2012). Due to its commercial interest, overfishing of mature females (that are aplacental viviparous and not prolific) poses a threat for resilience and conservation of this species (Echwikhi et al. 2013). Therefore, it is listed as "endangered" according to the IUCN Red List of Threathened Species (IUCN, 2014).

This study is to report on a new record of $R$. cemiculus from Kuşadası Bay confirming the presence of the species in the Aegean Sea.

\section{Results}

Brief description of the specimen in formalin

Body very elongate and flattened, covered with small dermal denticles; wedge-shaped snout with rostral ridges narrowly separated. Distance between rostral ridges less than eye diameter. Anterior nasal lobes 


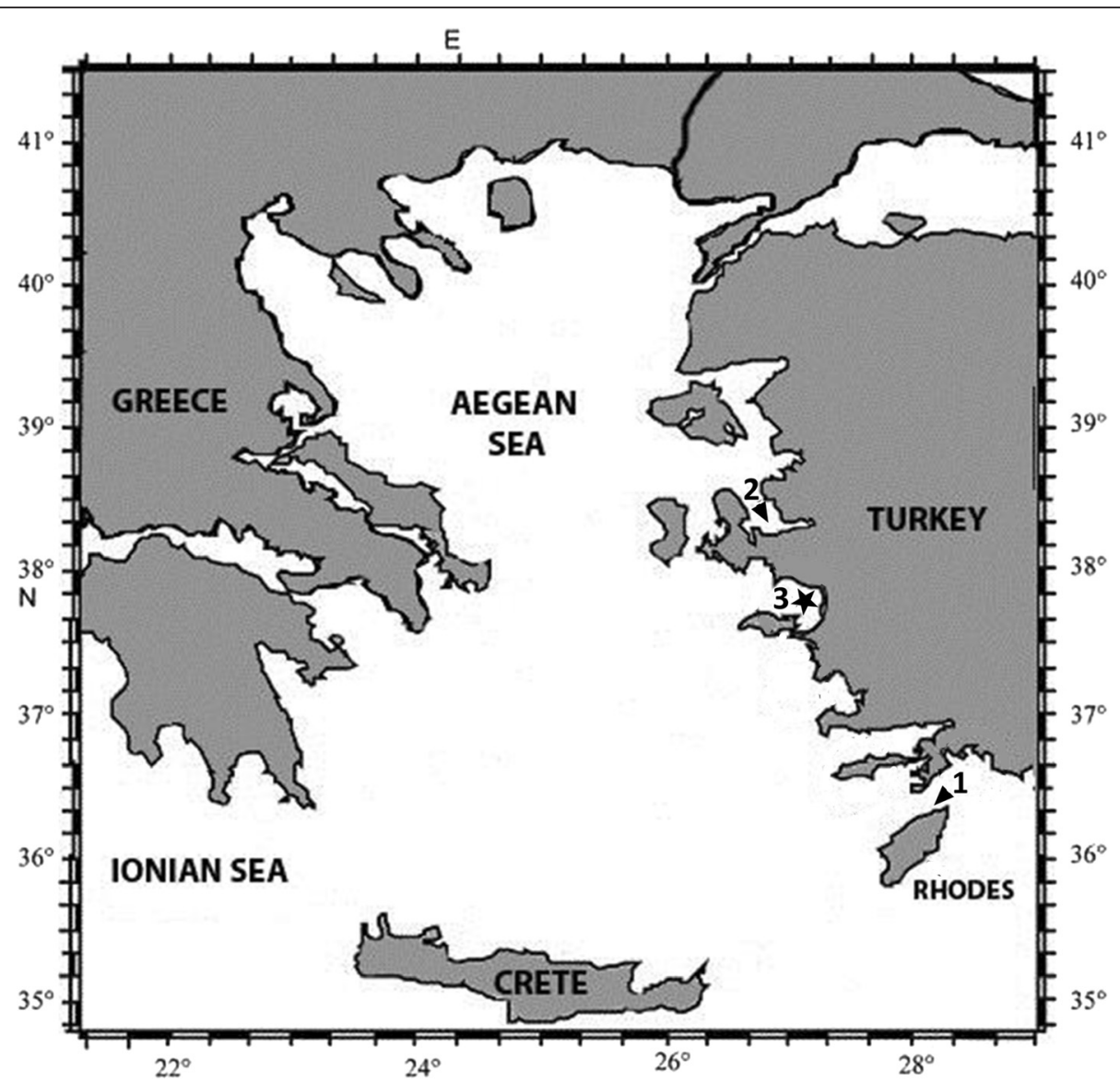

Fig. 1 Map showing the locations of Rhinobatos cemiculus records in the Aegean Sea (1-Corsini-Foka (2009), 2- Akyol and Capapé (2014), 3-Present study)

not reaching to level of inner corner of nostril (Fig. 2). Eyes relatively small. Numerous small teeth in payement pattern on jaws. Of the well-developed two dorsal fins the first beginning behind hind tip of pectoral fins. Thorns situated around inner margins of orbits, between spiracles and on shoulders, along midline of body and tail. Dorsal colouration olive green to brown, pale white below; snout and rostral ridges semi-transparent, beige upper limbs of dorsal fins. Selected morphometric (in $\mathrm{mm}$ ) values of $R$. cemiculus were measured as follows: TL $925 \mathrm{~mm}$, precaudal length $787(85.1 \% \mathrm{TL})$, disc length 280 (30.2 \% TL), disc width $315(34.0 \% \mathrm{TL})$, orbit diameter $12(1.3 \%$ TL), predorsal length 182 (19.7\% $\mathrm{TL})$, preorbital length $162(17.5 \% \mathrm{TL})$, interorbital width 52 (5.6 \% TL), preoral length 182 (19.7 TL), mouth width 64 (6.9\% TL).

\section{Discussion}

According to the previous records of $R$. cemiculus in the Mediterranean, this species is considered as a rare fish and its eastward distribution appears to be limited in the South Aegean Sea (Fig. 1).

To evaluate the settlement success of any species, information on reproduction of the species is required. In the Mediterranean, Capapé and Zaouali (1994) reported that females of $R$. cemiculus reach maturation at $1000 \mathrm{~mm}$ TL (Tunisian waters) while Ali et al. (2008) in Syrian coasts and Enajjar et al. (2012) in Gulf of Gabès observed for females a length at first maturity of $873 \mathrm{~mm} \mathrm{TL}$ and $1381 \mathrm{~mm}$ TL, respectively. The specimen collected in this study was immature, as no developing or ripe oocytes, embryos and fetuses were observed by dissection. The sexual maturity and maximum length range in fishes can be affected by a number of factors, such as temperature, food availability, light regime, oxygen, salinity, pollutants, predator density, genotype and overfishing (Bone and Moore, 2008). On the basis of our findings, it is not possible to report the presence of a breeding population of the species in the South Aegean Sea. Further research and monitoring studies are strongly suggested to clarify the population status of $R$. cemiculus in this area. 


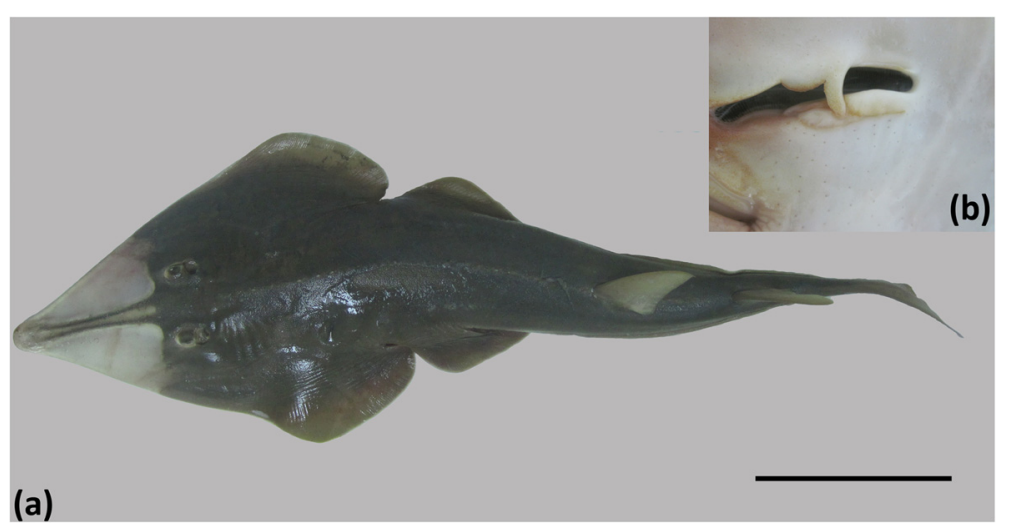

Fig. 2 Rhinobatos cemiculus collected from Kuşadası Bay, January 2015 (a) Total dorsal view, (b) left nostril (scale bar = 200 mm)

\section{Conclusions}

On the basis of citizen science, we observed and reported blackchin guitarfish, Rhinobatos cemiculus, from the South Aegean Sea. This study provides a prior knowledge about distribution range of endangered elasmobranch species in the Aegean Sea for biologists.

\section{Methods}

On 11 January 2015, a single female specimen of $\mathrm{R}$. cemiculus (925 mm total length (TL)) (Fig. 2) was collected by longline from Kuşadası Bay $\left(37^{\circ} 52^{\prime} \mathrm{N}, 27^{\circ}\right.$ $13^{\prime} \mathrm{E}$ ) on a sandy bottom at a depth of approximately $20 \mathrm{~m}$. The specimen was taken to the Laboratory of Fisheries Faculty of Muğla Sıtkı Koçman University (Turkey), for further examination, where the main morphometric measurements were collected by means of a digital calliper (to the nearest $0.01 \mathrm{~mm}$ ). The individual was identified based on criteria by McEachran and Capapé (1984), based on its morphometric measurements. Following the identification, it was fixed in $4 \%$ formalin and cataloged in the Faculty of Fisheries of Muğla Sıtkı Koçman University Collection Museum under the number MUSUM/PIS/ 2015-2. Scientists are welcome to have access to the biological material at will.

\section{Competing interests}

The authors declare that they have no competing interests.

\section{Authors' contributions}

HF participated in the identification of the species, supporting literatures and contributed to draft the manuscript, GB processed the images and contributed to draft the manuscript. DG checked the manuscript for grammatical errors and contributed to draft the manuscript. SY received the specimen, participated in the identification of the species, created to draft the manuscript, supported with the bibliography sources and is the corresponding author. All authors read and approved the final manuscript.

\section{Acknowledgements}

We wish to thank the local fisherman from the Kuşadası Bay for providing the specimen and Dr. Christian CAPAPÉ for helping identification of specimen. Also, the authors would like to thank the anonymous reviewers for their suggestions and comments.

\section{Author details}

${ }^{1}$ Faculty of Fisheries, Muğla Sıtkı Koçman University, Kötekli, Muğla, Turkey. ${ }^{2}$ Faculty of Science, Muğla Sıtkı Koçman University, Kötekli, Muğla, Turkey.

Received: 17 February 2016 Accepted: 23 February 2016

Published online: 11 April 2016

\section{References}

Ali M, Saad A, Kurbaj H. Reproductive cycle and size at sexual maturity of Chondrichthyan fish Rhinobatos cemiculus (Rhinobatidae) of the Syrian marine waters. Ann Agric Sci. 2008;46:21-30. (article in Arabic with an abstract in English).

Akyol O, Capapé C. Distribution of blackchin guitarfish Rhinobatos cemiculus E. Geoffroy Saint-Hilaire, 1817 (Elasmobranchii: Rhinobatidae) with first records from Izmir Bay (Turkey, northeastern Aegean Sea). Turk J Zool. 2014;38:460-5.

Başusta A, Başusta N, Sulikowski JA, Driggers WB, Demirhan SA, Çiçek E. Lengthweight relationships for nine species of batoids from the Iskenderun Bay, Turkey. J Appl Ichthyol. 2012;28:850-1.

Ben-Tuvia A. Mediterranean fishes of Israel. Bull Isr Sea Fish Res Stns. 1953;8:1-40. Bone Q, Moore R. Biology of fishes. 3rd ed. Abingdon: Taylor \& Francis; 2008. Capapé C, Guélorget O, Vergne Y, Marquès A, Quignard JP. Skates and rays (Chondrichthyes) from waters off the Languedocian coast (southern France, northern Mediterranean). Ann Ser Hist Nat. 2006;16:166-78.

Capapé C, Zaouali J. Distribution and reproductive biology of the blackchin guitarfish, Rhinobatos cemiculus (Pisces: Rhinobatidae), in Tunisian waters (central Mediterranean). Aust J Mar Freshw Res. 1994:45:551-61.

Corsini-Foka M. Uncommon fishes from Rhodes and nearby marine region (SE Aegean Sea, Greece). J Biol Res Thessalon. 2009;12:125-33.

Echwikhi K, Saidi B, Bradai MN, Bouain A. Preliminary data on elasmobranch gillnet fishery in the Gulf of Gabés, Tunisia. J Appl Ichthyol. 2013;29:1080-5.

Enaijar S, Bradai MN, Bouain A. Age, growth and sexual maturity of the blackchin quitarfish Rhinobatos cemiculus in the Gulf of Gabès (Southern Tunisia, Central Mediterranean). Cah Biol Mar. 2012:53:17-23.

Golani D. The marine ichthyofauna of the eastern Levant-history, inventory and characterization. Isr J Zool. 1996:42:15-55.

IUCN. 2014 The IUCN Red list of Threatened Species. http://www.iucnredlist.org Accessed date 11 February 2015.

Lloris D, Rucabado J. Guide FAO d'identification des espèces pour les besoins de la pêche. Guide d'identification des ressources marines vivantes pour le Maroc. Rome, Italy: FAO; 1998.

McEachran JD, Capapé C. Rhinobatidae. In: Whitehead PJP, Bauchot ML, Hureau JC, Nielsen J, Tortonese E, editors. Fishes of the North-Western Atlantic and the Mediterranean, vol. I. Paris, France: UNESCO; 1984. p. 156-8.

Mejri H, Ben Souissi J, Zaouali J, El Abed A, Vergne Y, Guélorget $O$, et al. On the recent occurrence of elasmobranch species in a perimediterranean lagoon: the Tunis Southern Lagoon (Northern Tunisia). Ann Ser Hist Nat. $2004 ; 14: 143-58$. 
Seck AA, Diatta Y, Diop M, Guélorget O, Reynaud C, Capapé C. Observations on the reproductive biology of the blackchin guitarfish, Rhinobatos cemiculus $\mathrm{E}$. Geoffroy Saint-Hilaire, 1817 (Chondrichthyes, Rhinobatidae) from the coast of Senegal (eastern tropical Atlantic). Sci Ger. 2004;27:19-30.

Tortonese E. Fauna d'Italia 2. Leptocardia, Ciclostomata, Selachii. Bologna, Italy: Calderini; 1956

Submit your next manuscript to BioMed Central and we will help you at every step:

- We accept pre-submission inquiries

- Our selector tool helps you to find the most relevant journal

- We provide round the clock customer support

- Convenient online submission

- Thorough peer review

- Inclusion in PubMed and all major indexing services

- Maximum visibility for your research

Submit your manuscript at www.biomedcentral.com/submit 